\title{
片頭痛に対する $\mathrm{S}$ 点ブロック \\ 及び良導絡治療法について
}

\section{はじめに}

脳神経外科外来に受診する患者の主訴の 70 〜 80\% が頭痛である。診察にあたる医師は、こ の頭痛を訴えて来る患者を診て、器質的疾患 （脳動脈瘤、脳腫瘍など）の有無について診断を 下すのに頭を悩ます訳である。

市立函館病院脳神経外科外来で、著者が実際 に診断し、保存的治療のみでよい所謂頭痛患者 に対して、主に良導絡治療法を行っている。今 回は、片頭痛の症例に対して、著者が行ってい る $\mathrm{S}$ 点ブロック法及び良導絡治療法の効果に ついて若干の文献的考察を加えて報告する。

\section{1. 頭痛の分類}

頭痛の分類に就いては種々の分類法が提唱さ れてきているが、それぞれに一長一短があり、 いまだ統一された分類法は確立されていない。 そのうち 1962 年 NIH 頭痛分類学会 (Ad Hoc commitee on classification of headache)
北海道 清 水一志

による分類法（頭痛の発生機序に基ずく分類 法) ${ }^{2)}$ が一般に最も広く用いられている。(第 1 表)

しかし、この分類法であ、顔面、耳、鼻、口腔、 及び頸部まで含めた部位の痛みなどと頭痛を広 く解釈している点が、いまだ議論の余地を残し ている。

\section{2. 片頭痛の定義}

前記の分類法によれば、頭部血管に起因する 頭痛の内で慢性、反復性で器質的な異常が無 く、第 2 表に示す如き臨床症状を有する一群の 頭痛を片頭痛と定義している。

この分類に含まれているものとしては、古典 型片頭痛、普通型片頭痛、群発頭痛、片麻瘏型 並びに眼筋麻摩型片頭痛などが挙げられる。

これら片頭痛の子細な鑑別診断については、 他の成書に譲るが、大まかな要点を第 3 表に記 載する ${ }^{1}$ 。

このうち、片麻痺型及び眼筋麻痺型片頭痛は

第 1 表 Ad Hoc Committee の頭痛分類

I. 片䫝施型血管性頭捅 (Vascular headache of migrame type)

1) 古典型片頭第 (“Classic” migraine)

2 ) 型通版頭㾁 (“Common" migraine)

3 ) 群発頭并 (“Cluster" headache)

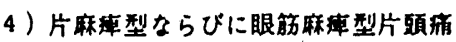
("Hemiplegic" migraine and "opthalmoplegic" migraine)

5 ) 下半分頭㾁 ("Lower half" headache)

II. 笳収摍性頭㾁 (Muscle-contraction headache)

II. 混合性頍痛 (Combined headache : vascular and muscle contraction)

Ii. 血管運较性頭病 (Headache of nasal vasomotor reaction)

V. 妄想, 転换反応，心気症による頭旃 (Headache of delusion, conversion or hypochondrial states)

11. 非片頭痛型血管性頭㾈 (Nonmigrainous vas- cular headache)

V. 连引性频船 (Traction headache)

V. 頭部炎庭による頍庰 (Headache due to overt cranial inflamation)

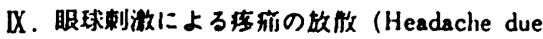
to ocular disease)

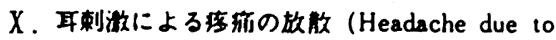
aural disease)

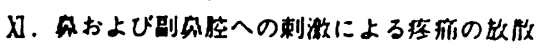
(Headache due to nasal and sinus disease)

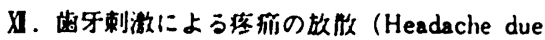
to dental disesse)

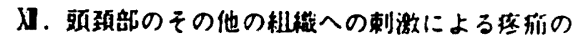
故脱 (Headache due to disease of other cranial or neck structure)

XI. 歌部神経炎 (Cranial neuritis)

$X^{\prime}$. 衉部神䅅侕 (Cranial neura:' ia) 
1) 家族性が胎い.

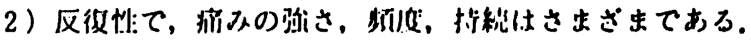

3）片例性の欧痛として始ることが多い.

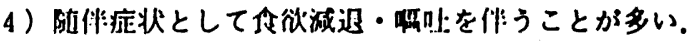

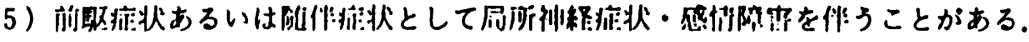

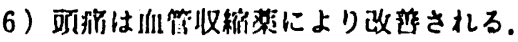

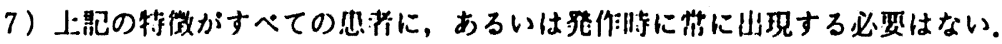

第 3 表 片頭痛の鑑別の要点

\begin{tabular}{|c|c|c|c|c|c|c|c|c|c|c|c|}
\hline 㩆 & 扁 & $\begin{array}{c}\text { 性 } \\
(\text { 只: 女) }\end{array}$ & 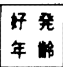 & 造伝 & 部 位 & 性 䆩 & 持楮时成 & 频 & 出現模式 & 随伴症状 & 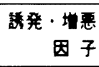 \\
\hline 片 & 盖 & $\begin{array}{l}n<女 \\
(1: 3)\end{array}$ & $\begin{array}{c}10 \\
1 \\
20 \\
1 \\
\text { 代 }\end{array}$ & 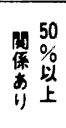 & 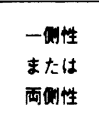 & 拍勘性 & $\begin{array}{l}6 \text { 時间 } \\
2 ， 3 \text { 日 }\end{array}$ & $\begin{array}{c}\text { 监冓性 } \\
\text { (月に1〜2回) }\end{array}$ & $\begin{array}{l}\text { 徐々に } \\
\text { 出 現 }\end{array}$ & 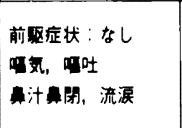 & $\begin{array}{l}\text { 疲労, 月経 } \\
\text { 睡眠中 } \\
\text { 沽朝 } \\
\text { 虾酒 }\end{array}$ \\
\hline 牌 & $\begin{array}{l}\text { 克 } \\
\text { 型 } \\
\end{array}$ & $\begin{array}{l}n<女 \\
(1: 3)\end{array}$ & $\begin{array}{c}10 \\
1 \\
20 \\
1 \\
10+1\end{array}$ & 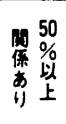 & 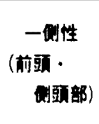 & 拍钩性 & $\begin{array}{r}2 \text { 時间 } \\
\text { 半日位 }\end{array}$ & $\begin{array}{c}\text { 兴性 } \\
\text { (月に1〜2回) }\end{array}$ & $\begin{array}{l}\text { 急娍に } \\
\text { 出 现 }\end{array}$ & 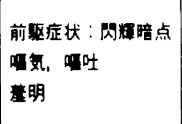 & 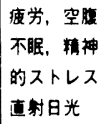 \\
\hline 䫑 & 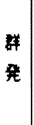 & $\begin{array}{l}\text { n>女 } \\
(5: 1)\end{array}$ & $\begin{array}{c}30 \\
1 \\
60 \\
1 \\
\text { 代 }\end{array}$ & 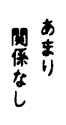 & $\begin{array}{l}\text { 一夥性 } \\
\text { (特に } \\
\text { 眼葢部) }\end{array}$ & 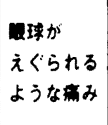 & $\begin{array}{r}1 \text { 時间 } \\
2 \text { 時间 }\end{array}$ & $\begin{array}{l}\text { 出現時に } \\
\text { は帠発 } \\
\left(\begin{array}{l}\text { 春，秋に } \\
\text { 多い }\end{array}\right)\end{array}$ & $\begin{array}{c}\text { 急清に } \\
\text { 出 現 } \\
\text { (夜时に多い) }\end{array}$ & $\begin{array}{l}\text { 前聚症状：なし } \\
\text { 閉，流涺 } \\
\text { Horner 症侯群 }\end{array}$ & $\begin{array}{l}\text { 棈神的 } \\
\text { ストレス. } \\
\text { 疲労 } \\
\text { 欲酒 }\end{array}$ \\
\hline
\end{tabular}

第 4 表 良萛絡の発生機序（Lance 改変）

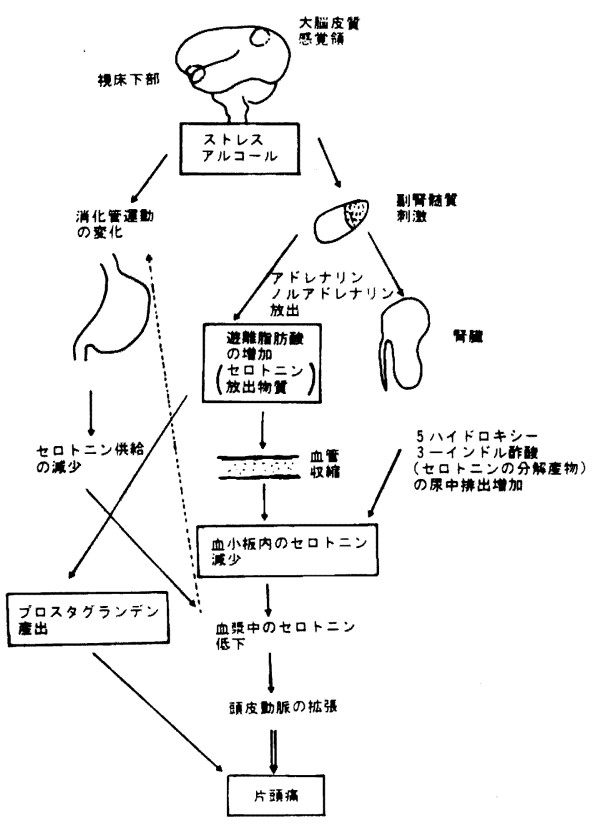

(Lance e变)
稀なもので、頭痛発作と前後して片麻痺、言語 障害、眼筋麻痺等の一過性神経症状が出現する 片頭痛である。著者も2 例の片麻痺型の症例を 経験したが、いずれも女性で諸家の報告と同様 20 才代であった。一方、眼筋麻痺型は男性に好 発し、30才以前に発症するのが多い。

\section{3. 片頭痛の発生機序}

片頭痛の発生機序に関しては、いまだ子細に 解明されていないが、病態としては、頭蓋内外 血管が異常収縮反応、ついで拡張を起こすこと が明らかとなった。これら異常血管反応に対す る機序として、セロトニン、プロスタグランデ ンなどの代謝異常説と血管運動中枢の調整障害 説が唱えられている1。（第 4 表）即ち、発作先 駆症状期は血小板から放出されたセロトニンに より脸血管が収縮し、その結果、局所脳虚血症 状が生じ、閃輝暗点、羞明、特には視野欠損が 生ずる。その後、血中セロトニンは分解されて 尿中に排泄されるために、血中セロトニン濃度 
が二次的に減少し、また、血中遊離脂肪酸より プロスグランデンが産出され、脳血管の拡張を 起こし、拍動性頭痛が出現する、とされている。 さらに血管拡張に伴って血管壁の浮腫、血管透 過性の昂進により、セロトニン、プラスマキニ ン、プロスタグランデン等が血管壁に作用し、 痛覚感受性を過敏化し、持続性頭痛となる。こ の時期に内頸動脈が走る海綿洞内で、内頸動脈 に浮腫を起こし、外眼筋を支配する脳神経（外 転、滑車、動眼神経）海綿洞に沿って走行し ているため、压迫され眼筋麻疸を起こすとされ ている8。

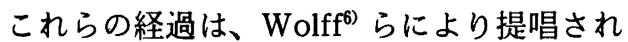
た片頭痛の Vasucular theory に基ずいてい る。近年、RI 脳循環測定法、DynamicCT、な どによる片頭痛の症例に対する局所脳血流量測 定が可能となり、この脳血流量循環測定より、 片頭痛発作の病態は、皮質感覚領、視床下部の 機能障害が第一次的な原因と考え、脳の血管の 異常収縮、拡張は二次的な現象であることが解 明されてきだ),7)。(ずれにしろ、自律神経系、 内分泌系、血液凝集系、中枢神経系などが密接 に関与していることが明かとなった。

\section{4. 片頭痛の診断}

片頭痛の診断に当たっては、先記の片頭痛の 鑑別診断要項と共に、他の頭痛との鑑別が必要 である。このためには患者よりの詳しい問診に より、頭痛の発症様式（急激か、次第に強くな るか、同じか)、頭痛の性格（突き刺すような、 脈を打つような、締め付けられるような)、頭痛 部位（頭全体か、限局的か、）、随伴症状、既往 暦、家族暦等を出来るだけ子細に聴取すること が重要である。(従って問診によって、ある程度 頭痛の分類が可能である。）

次に、子細に神経学的検査及び、各種の補助 診断法を行う。即ち、頭部 (又は頸部) 単純レ 線撮影、腰椎穿刺、脳波、CT スキャン、脳血管 撮影、RI 脳血流量測定等その他、第 5 表の如き 諸検查を組み合わせて、器質的疾患の有無をチ エックする。

片頭痛を診断する場合には、少なくとあ頭部 （又は頸部）単純写、脳波、CT スキャンなどの 補助診断法は行う必要がある。
第 5 表 頭痛の診断法

和器時：

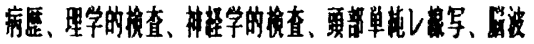

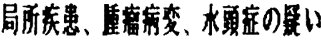

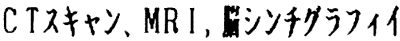

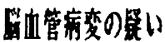

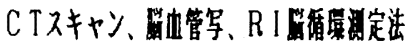

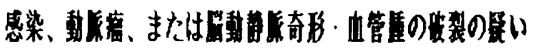

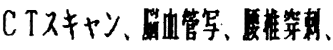

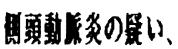

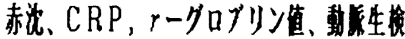

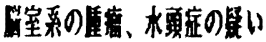

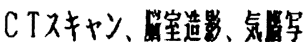

预椎获患の㜊い

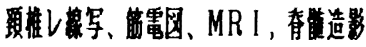

(Diamond, S \&Dalessio 0. J :

The practicingPhysician s approach to headache, 2 nd ed. 1978 を一部就し(引用)

5. 治療法

A）薬物療法

現在広く用いられている片頭痛の薬物療法と しては、麦角アルカロイド製剤（ミグタミン、 ベレルガル、カフェルゴット、など)、抗セロト ニン剂 (ペリアクチン、ミグリステンなど)、及 び最近欧米で注目されてきた Ca 拮抗剤（メチ セルジド、プロプラノールなど）に大別される。

麦角アルカロイドの一種であるエルゴタミン は昔から強力な血管収縮作用を有し、産科で常 用されている。片頭痛の発生機序が頭蓋内外血 管の異常拡張、伸展により発現することから、 片頭痛に対するエルゴタミン製剤を投与して血 管の収縮をはかり、頭痛発作を止めようとする 治療法であるが、実際には頭痛発作時に投与し 
てむ、あまり効果が無く、むしろ発作前又は間 欠期に投与すると効果がある。しかし、本剂の 長期連用により高血圧、狭心症、脳梗塞等を併 発することがあるので、本剤を長期に投与する ときは注意しなければならない。

一方、前記の血小板より放出されたセロトニ ンが片頭痛発作の引き金とする Lance 等のセ ロトニン学説や、脳内のセロトニンの減少によ り痛覚成値が低下することにより偏頭痛が生ず るとの学説に基ずいて、セロトニンが片頭痛発 作に色々と関与していることが明かとなり、前 記の各種の抗セロトニン製剤が片頭痛の発作間 欠期に使用されるようになった。

$\mathrm{Ca}$ 拮抗剂は血管の平滑筋、心筋細胞膜の calucium channel を阻害し、 $\mathrm{Ca}^{++}$の細胞内流 入を抑制することにより、血管平滑筋の収縮能 を上昇させる作用を持っている。これまで狭心 症、不整脈、高血圧、などの心血管病変にひろ く治療薬として用いられてきたが、最近では脳 血管攣縮、片頭痛予防薬としても試みられてき ており、良好な効果が報告されるようになって

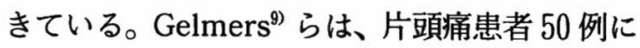
nimodipine $120 \mathrm{mg} /$ day を投与し、約 $69 \%$ に 発作頻度の低下を報告している。

その他、 $\beta$ 一ブロッカー剂（プロプラノール、 ピンドロールなど）も脳血管拡張を抑制すると 共に、エピネフリンによる血小板凝集作用を抑 制するため、普通型片頭痛の予防薬として使用 される。又、脳波検査で異常を認める症例に対 して、抗痙攣剤である phenytoin（アレビアチ ン）の投与が勃果がある。

\section{B）漢方薬治療}

最近では、我が国の医療の中で漢方治療が次 第に注目され、多くの大学病院や大病院などで も投与され、又、漢方薬の効用についての研究 発表む、数多く為されるようになってきたこと は、今まで漢方治療を行ってきた医師達にとっ ては、誠に喜ばしいことである。

慢性に経過する頭痛に対して漢方薬の投与 は、最も効果を期待される治療法の一つであ る。

片頭痛の治療に常用される漢方薬としては、 呉茱莫湯、当帰四逆加点茱莫生姜湯、五苓散、
等が使用されている。（投与法などは専門書を 参照のこと。）著者あ良導絡治療と共に、点荣 莫湯、女神湯、などの漢方薬を併用して投与し、 かなりの効果を得ている。

C） S 点ブロック法及び良導絡治療法

従来より脳神経外科、麻酔科において片頭 痛、頸椎捻挫、末梢性顔面神経麻盘、メニエー ル氏病、帯状包疹、Raynaud 病、BÜrger 病、 突発性難聴、耳鳴、眩量などの症例に対して星 状神経節ブロック（以下 SGB と省略）が行わ れてきており、かなり効果を得ている。本法の 作用機序はまだ明らかでないが、交感神経系の 興奮状態を鎮静、又は痛覚伝導繊維の遮断など が考えられている。

著者は、SGB の針治療の応用として、ノイロ メータを用いて SGB 部位 (S 点と名称する) に 刺針し、痛電しながら、雀豚する方法で前記の 疾患に対して行い、SGB 療法に負けず少らず の良好な効果をえた。このため、最近では片頭 痛の症例に対しても、他の反応良導絡点治療と 共に、本法の併用を行っている。

\section{図1 S 点ブロック施工中の風景}

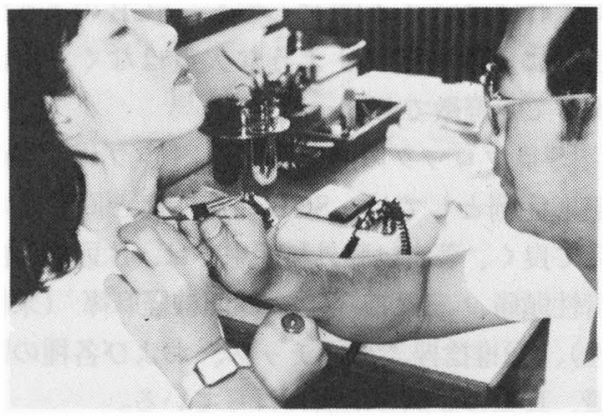

第 6 表 8 点ブロック治療例

\begin{tabular}{|c|c|c|c|c|c|c|}
\hline 症例 & 年秢 & 性別 & 期 間 & $\mathrm{S}$ 点治数回数 & 阱用菜 & 予後 \\
\hline K.M. & 21 & 女 & $\begin{array}{l}\text { S. } 59.4 .26 \\
\text { S. } 60.3 .25\end{array}$ & $\begin{array}{c}\text { 34回 } \\
\text { (週1 2回) }\end{array}$ & 呉荣英湯 & 治虑 \\
\hline N.M. & 21 & 男 & $\begin{array}{l}S .59 .1 .19 \\
\text { S.59.7.23 }\end{array}$ & $\begin{array}{c}22 \text { 回 } \\
\text { (週1 2回) }\end{array}$ & $\begin{array}{c}\text { なし } \\
\text { (肝炎あり) }\end{array}$ & 治意 \\
\hline K. T. & 32 & 女 & $\begin{array}{l}\text { S.59.11.26 } \\
\text { S.60.9.5 }\end{array}$ & $\begin{array}{c}\text { 25回 } \\
\text { 週1 2回 }\end{array}$ & $\begin{array}{l}\text { 题䒩莫湯 } \\
\text { 女晹 }\end{array}$ & 治透 \\
\hline J.T. & 51 & 女 & $\begin{array}{l}\text { S.59. }{ }_{\mathbf{j}}^{9.22} \\
\text { S. } 60.10 .15\end{array}$ & $\begin{array}{c}\text { 15回 } \\
\text { 遇 } 1 \sim 2 \text { 2回 }\end{array}$ & \begin{tabular}{ll|} 
Tofranil & $30 \mathrm{mg}$ \\
Cercine & $6 \mathrm{mg}$
\end{tabular} & 柽快 \\
\hline T. A. & 32 & 女 & $\begin{array}{l}\text { S.60.10.21 } \\
\text { S. } 61.2 .24\end{array}$ & $\begin{array}{c}\text { 11回 } \\
\text { 週 1 2回 }\end{array}$ & 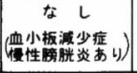 & 怪快 \\
\hline
\end{tabular}


［S 点ブロックの手技］座位または仰臥位で 頸部をできるだけ後屈させる。次いで胸骨陥没 部より外側へ 2 横指、上方に 2 横指の部位に刺 針するが、その際、左指で総頸動脈の拍動を触 知し、これを外側に圧排し、動脈を穿刺せぬよ うに注意する。刺針は一度椎体に針を当てた 後、約 $5 \mathrm{~mm}$ 引き戻した部位で、約 100 回、通電 しながらゆっくり墔豚するか、置針したまま約 $10 \sim 15$ 分間の通電を行う。(図 1 )

[S 点ブロックの長所、欠点 ] SGB は局所麻 酔剂を使用するため、麻酔剤によるショック、 頸動脈内又は椎骨動脈内誤注入による痤撃発 作・ショック、肺気腫を起こすことがある。又、 一過性であるが、Horner 症候群 (眼球陥没、眼 睑下垂、縮瞳、患側無汗症)、嗄声などの不快な 副作用を生じる。これらの SGB ブロックの欠 点や副作用は、S 点ブロックでは皆無であるこ とが本法の長所である。欠点としては、乳幼児 には頸部を一定時間固定出来ないために困難で あること、小血管を誤刺して皮下出血を起こし たり、腕神経叢を誤刺し、頸部〜胸部〜上肢に かけて疼痛を訴える事がある。（この場合には 一度針を抜いて、少し針の位置をずらして、再 刺すれば良い。）何れにしてむ、SGBのように 生命に危険を及ぼすような欠点はなく、また あっても軽微である。

[S 点ブロックの適応症例 $] \mathrm{S}$ 点ブロックの 適応症例としては、SGB の適応症と同じと考 えて良く、著者は脳外科疾患では、片頭痛、血 管性頭痛、三叉神経痛、顔面神経麻痺（末梢 性)、頸椎捻挫、顔面チック、および各種の眩 量、耳鳴の症例の治療に行っている。

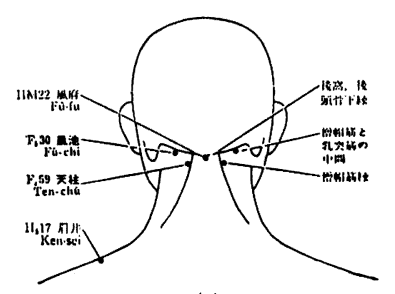

$\underset{\text { Dai.tui }}{\text { IINize }} V_{c}$

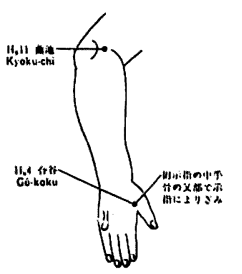

図2 著者が主に使用している反応良導絡点
[良導絡治療法］この S 点ブロック法と良 導絡の反応良導点（図 2$)$ である天柱 $\left(F_{2} 59\right)$ 、 風池 $\left(\mathrm{F}_{5} 30\right)$ 、風府 $(\mathrm{HM} 22)$ 、肩井 $\left(\mathrm{H}_{5} 17\right)$ 、大 椎 (HM 20)、百会 (VM 26)、などの穴に通電 しながら、約 2 分ずっ隹啄を行う ${ }^{5}$ 。

[S 点ブロック及び良導絡治療法の効果］著 者が治療を行った 5 例の普通型片頭痛症例を第 6 表に示すが、女 4 例、男 1 例であり、年 齿は $21 〜 51$ 才（平均年齢 31.4 歳）で諸家の 報告と同様に青年層に多い。本法施行は週 1 2 回、 $11 \sim 34$ 回の治療で何れあ治瘾又は軽快 している。

併用薬としては、吳荣英湯、女神散などの漢方 薬や三環系抗うつ剤やマィナトランキライザー を 3 例に投与したが、他疾患を合併する 2 症例 には併用薬は投与せず、本法のみの治療を行っ た。

\section{まとめ}

頭痛を訴えて脳神経外科の外来を受診してく る患者は多い。しかし脳外科的適応（観血的療 法）を要する患者は極く僅かであり、その他の 多くの患者は、対症療法のみで良い患者であ る。

これらの患者に対して、脳外科医は各種の治療 法（投薬、物療、ブロックなど）で治療を行っ てきている。

著者は、これら対症治療のみで良い患者に対 して、良導絡治療を主にして、治療してきてい る。今回は、主に片頭痛の症例に対しての、現 在の片頭痛の病因論、主な治療法について述 へ、さらに、著者が治療を行っているSGBを 応用した S 点ブロック、良導絡治療法について 報告した。

特に、S 点ブロック法は SGB に比べて、ほと んよ゙副作用や危険性が無く、その効果は SGB と同様か、それ以上の効果を得た。

本法の作用機序は、その作用が速効性がある ことより、交感神経系に関係が密接であると考 えられるが、子細な作用機序は不明であり、今 後、検討すべき問題点であると思われる。 


\section{文 献}

1）佐野圭司 その他：頭痛 診断と治療、現 代医療社、1981。

2) The Ad Hoc Committee on Classification of Headache, Arch. Neurol., $6: 173-$ 176, 1962 .

3 ) Lauritzen. M., et al : Changes in Regional Blood Flow During the Course of Classic Migraine Attacks, Ann Neurol, 633, 1983。

4) 清水常正、その他：片頭痛発作時の脳血流 動態一臨床症状と dynamicCT一、第 15 回頭痛研究会会誌、9-11、頭痛研究会、 昭和 63 年。

5 ) 中谷義雄: 最新良導絡の臨床の実際、良導
絡研究所、1973。

6) Graham, J. R. \& Wolff, H. G. : Mechanism of migraine headeche and action of ergotamine. Arch. Neurol. Psychiat., $39: 737,1938$ 。

7 ) 坂井文彦、田崎義昭: 片頭痛一血管性頭痛、 Clin. Neurosci. 1 : 296-299、 1983.

8) Lance, J. M. : Serotonin, the carotid body and cranial vessels in migraine. Arch Neurol., $16: 553,1967$.

9) Gelmers, H. J. : Nimodipine, a new calcium antagonist, in the prophylactic treatment of migraine. Headache, 23 : 106, 1983. 